\title{
Race against death or starvation? COVID-19 and its impact on African populations
}

\author{
Melkamu Dugassa Kassa ${ }^{1,2^{*}}$ and Jeanne Martin Grace ${ }^{2}$
}

\author{
* Correspondence: kassam@ukzn.ac. \\ za \\ 'Discipline of Biokinetics, Exercise \& \\ Leisure Sciences, College of Health \\ Science, University of \\ KwaZulu-Natal, 2nd Floor Q Block, \\ Westville Campus, University Road, \\ Durban 3630, South Africa \\ ${ }^{2}$ Discipline of Biokinetics, Exercise \& \\ Podiatric Medicine, College of \\ Health Science, University of \\ KwaZulu-Natal, Westville Campus, \\ University Road, Durban 3630, \\ South Africa
}

\begin{abstract}
Background: Born in the Chinese city of Wuhan, the consequences of the coronavirus pandemic on global health and economies have been and continue to be devastating. In Africa, its countries grieve for unprecedented burdens of caseloads and mortality due to COVID-19, the virus responsible for the disease. This narrative review aims to establish the scale of the health and economic crisis wrought by the pandemic in Africa, including its impact on the informal economic sector, projections of the effect on national GDP, as well as its political dimensions.
\end{abstract}

Methods: Documentary evidence issued between January and 8 August 2020 was sought from the Google Scholar, PubMed, Scopus, and Web of Science databases. Searches of published and unpublished abstracts were also conducted from appropriate websites, government documents, organizational reports, newspaper commentaries, and reports issued by global, regional, and local centers of disease control and prevention.

Results: The COVID-19 pandemic is responsible for a fourfold crisis in Africa: (1) a health crisis: the victimization of frontline healthcare workers and the looming caseload and death tolls with 1.039 million (12\%) cases being confirmed and over 22, 966 (2.4\%) deaths as of 8 August 2020. The highest death toll was recorded in Southern Africa of 11,024 (48\%) followed by North Africa with 6,989 (29.2\%) deaths; (2) a social crisis: with the violation of human rights, the killing of citizens by security forces and increased crime. This, in turn, exacerbates social inequalities, the breakdown of households, instances of social unrest, and general impoverishment; (3) an economic crisis: manifested by a decline in GDP and mass unemployment; (4) a political crisis: implementation of measures that may not be appropriate for Africa, discrimination of refugees and immigrants, evacuation of citizens to their home countries, resulting in distrust of political leaders and postponement of national elections, and mounting cases of conflicts and unrest.

Conclusion: Lockdown during the COVID-19 outbreak is a prevention mechanism in affluent countries, in contrast to developing regions such as Africa, where it is a race against death and starvation. Policymakers must apply novel and locally relevant prevention and management strategies to cope with this growing disaster.

Keywords: Africa, Coronavirus disease, Economic impact, GDP, Political crisis, Social impact 


\section{Background}

The rapid and global spread of the coronavirus disease due to COVID-19 poses the greatest public health and economic crisis the world has faced in over a century. It affects all races, genders, and religious groups, regardless of their economic status [1, 2]. The widespread and growing prevalence of the virus throughout the world is associated with the movement of people from its origins-in the Chinese city of Wuhan - to other, previously non-infected areas due to the easy movement of people through work, tourism, trade, and international travel [3, 4]. As the prevalence of the COVID-19 outbreak and its associated morbidity and mortality are dramatically increasing, it poses significant limits on freedom of social life, liberty of travel, social cohesion, and productivity among the global community [5, 6].

Following the spread of the disease across and then outside China, on 3 January 2020, the World Health Organization (WHO) declared the situation a global public health emergency-calling it a pandemic for the first time-and expressed great apprehension about the need to safeguard countries with limited resources, fragile health systems, and lack of preparedness to avert the health crisis that was about to hit them $[7,8]$. Taking into consideration the possibility of the auxiliary consequences, the probable effect on human health, the efficiency of present-day readiness, and response measures, the WHO released US\$1.8 million from its Contingency Fund for Emergencies (CFE) to support preliminary preparation and response activities [9]. Realizing the growing number of cases in developed countries, and the inability of their health systems to deal with the overwhelming number of sick people who needed critical care, African countries such as Kenya, South Africa, Rwanda, and Uganda started to take preventive measures in early February 2020 that included lockdowns, flight bans, shutting down educational institutions such as schools and universities, closing international borders, banning public transport, and imposing curfews [10, 11].

The outbreak of COVID-19 devastated the networks of African populations, particularly as they affected meetings, tourism, travel, trade, and physical contact due to the territorial and boundary lockdown of countries to limit, and ideally prevent, the spread of the disease. It obliged African communities to keep in touch through advanced technologies, such as the internet, webinars, smartphones, and other electronic systems. Despite the lockdowns in many countries, COVID-19's prevalence and spread are escalating exponentially, with over 19.8 million cases and over 729,891 deaths at the time of finalizing writing of this article on 8 August 2020 [12]. The numbers that succumbed to the disease in other countries soon surpassed those recorded initially in China, such as the USA, Brazil, India, Russia, South Africa, and Mexico [13]. While the COVID-19 outbreak in China was in its maturation stage, it was at its peak in many developed countries such as, initially, Italy, then France, Germany, Spain, the USA, and the UK through transmission by contagious immigrants and then domestically [14].

The global impact of the disease is massive and overwhelming, causing extensive morbidity, mortality, social disintegration, and economic loss [15]. In Africa, the spread of the outbreak is in its growth stage-initially in Egypt, then Algeria, South Africa, Morocco, Ghana, and Nigeria with their considerable concern over a possible future high transmission rate due to poverty and socio-economic factors [16, 17]. Unlike European and other rich countries, the cultures of African populations are unique in that they appreciate collectiveness and cohesive life, which conflicts with the imposition 
of lockdowns, curfews, social distancing, and isolation, and no doubt increases the rates of transmission, morbidity, and mortality [18]. Mass gatherings at religious events, large-scale social occasions, traditional funerals, and wedding ceremonies are standard African cultural practices [19]. These, together with a lack of sufficient knowledge and information about the disease, and poor implementation of the information in practice, contribute to the spread of the coronavirus [20]. In contrast, evidence from countries such as China, Korea, Japan, and Turkey confirms that self-care and social isolation could significantly diminish the spread of infection [21]. If temporary cultural reform is not implemented in Africa, the number of cases and the death toll due to the outbreak will surpass the total global cases and deaths [19, 22].

In contrast to conditions in rich countries in the West, the lives of many Africans are based on the daily routine of obtaining enough food to survive [23, 24]. Subjecting African communities to lockdown at home for extended periods is impossible, as people need to access their fields or otherwise find a way to acquire food. For instance, in Ethiopia, Kenya, Nigeria, and South Africa, many have violated the lockdown measures [25-27] and moved through public spaces like restricted areas in towns and market places in large numbers to search for or collect their daily food, despite such moves being forbidden [28]. While lockdown is intended as a measure to reduce the outbreak of COVID-19 and prevent its transmission in the affluent world, it represents a race against death to survive among many in Africa, where life has become an "avoidanceavoidance" conflict situation; be locked in at home and die of starvation, or violate the lockdown regulations to work and collect food and die from the disease. Whatever citizens choose to do, the race is against death, from starvation, or the virus. In Africa, the public perspective about the morbidity and mortality wrought by the disease remains trivial [20], making it especially difficult to implement preventive mechanisms to stop its spread in most countries [29]. This huge obstacle is compounded by social practices: the impact of traditional greetings; poor sanitation (the injunction to wash hands with soap when clean water is scarce) [30]; material sharing, such as of door handles, toilets, television remotes, mobile phone, and computer keyboards; the general lack of caution and egotism that has been predicted to double the risk of coronavirus infections in Africa [31]. Evidence from China showed a marked decline in its transmission after material sharing was banned and lockdown and social distancing were implemented [32], which is impossible in Africa. This is because the majority of Africans live below the poverty line, and millions more are engaged in informal work. In Africa, even if they stay at home, these workers and their families remain exposed to the virus because of overcrowded and unsanitary living conditions that make physical distancing and hygiene nearly impossible. Moreover, most African populations lack access to running water that not only limits the possibilities for handwashing, but also forces women to queue for water, thereby risking themselves and these with whom they come into contact [32].

A community-based and self-care management approach to fight the coronavirus pandemic has been encouraged because of its extensive influence on morbidity and mortality globally, the resulting financial consequences, and the public significance of its prevention [33]. Effective measures against COVID-19 require collaboration among governmental and non-governmental organizations, private agencies, healthcare facilities, and social institutions, such as schools, universities, and religious centers, to mitigate the spread of the virus [34]. If appropriately implemented, such a collaborative effort will 
enable a healthcare system to cope better with its impact on high-risk individuals and groups as part of the global prevention strategy [35].

Evidence from Africa shows also that the prevalence of the disease is higher among people who travel abroad, gather in large numbers, wash their hands infrequently, have close physical contact with others, and share hand-used materials, all of which increases their opportunities to come into contact with infected people or the virus [36]. Transmission of the coronavirus continues to increase, and its prevalence has spread among all African regions, regardless of their healthcare system and economic level [37, 38]. This has raised the need for further health, social, economic, and political impact analysis studies to assist decision-makers regarding service delivery by indicating the public health requirements that need attention, and by estimating the funding and actions required for appropriate preventative measures. It is, therefore, essential to undertake a wide-ranging analysis when assessing the impact of the COVID-19 outbreak on the health and economic growth of poorly resourced countries, such as those in Africasuch studies not having been reported hitherto. The current evidence focuses mainly on the number of confirmed cases, recoveries, and deaths; the social, economic, and political impacts remain largely unknown. In this narrative review, we aimed to establish the number of COVID-19 cases, recoveries, and deaths; the health crisis's impact on the formal and informal economic sectors; and projections of gross domestic product (GDP) changes in Africa before, during, and potentially after the pandemic, as well as the political and other consequences of preventative measures such as lockdowns.

\section{Methods}

\section{Sources of information}

We conducted electronic searches of relevant reports, issued between January and 8 August 2020, extracted from the Google Scholar, PubMed Central, Scopus, and Web of Science databases. Also, we searched published and unpublished abstracts, as well as reference lists and tables of contents of relevant journals such as The Lancet, New England Journal of Medicine, and Nature; and examined African-related global and regional government documents, WHO global and regional reports, as well as updates from regional and local centers of disease control and prevention (RLCDC), and also newspaper commentaries from The Guardian (UK) and The Washington Post (USA).

\section{Search terms in the survey}

The following search terms were used: "infectious disease" AND "Corona Virus" AND "Wuhan, China" AND "COVID-19 outbreak" OR "COVID-19 Pandemic" OR "Prevalence of COVID-19", AND "Serious Acute Respiratory Syndrome (SARS)" AND "impact of COVID19" OR "economic impact of COVID-19" OR "informal economy" AND "Gross domestic product" OR "GDP" OR "health impact of COVID-19" OR "social impact of COVID-19" OR "political impact of COVID-19" AND "fatality due to COVID-19", AND "COVID-19 case report", OR "COVID-19 death reports" AND "social distancing" AND "lockdown".

\section{Selection criteria}

We two authors independently assessed all titles and abstracts of identified studies and applied the following four inclusion criteria to determine if the reports warranted 
further investigation: (1) did they include African counties? (2) were they published in English? (3) were the contents pertinent to the aim of the study? (4) were they published between January and July 2020? Full-text versions of journal articles or other source documents were obtained of studies that met the inclusion criteria; for those where this was unclear, we reached consensus after a discussion. From the final selection of source documents, we (J.G. and M.K.) independently abstracted data onto standard data forms. The authors of studies with missing data were contacted by email to obtain the data where possible.

\section{Estimates of gross domestic product}

The pre-pandemic, current, and post-COVID-19 GDP projections for Africa were calculated based on data drawn from the World Economic Outlook database for the continent $[39,40]$.

\section{Results of the search for source material}

Initially, we identified 136 studies using the search criteria (Fig. 1), using Mendeley Desktop reference management to identify duplication and data management. After removing duplications, checking the eligibility of full-text articles, applying exclusion criteria, and screening, 32 papers met the inclusion criteria.

\section{The health crisis in Africa}

Since the first case of COVID-19 in Africa was confirmed in northern Egypt on 15 February 2020, the pandemic and its associated morbidity and mortality have dramatically increased in the five regions of Africa (North Africa, Central Africa, East Africa, West Africa, and Southern Africa). As the virus reached the continent only 3 months

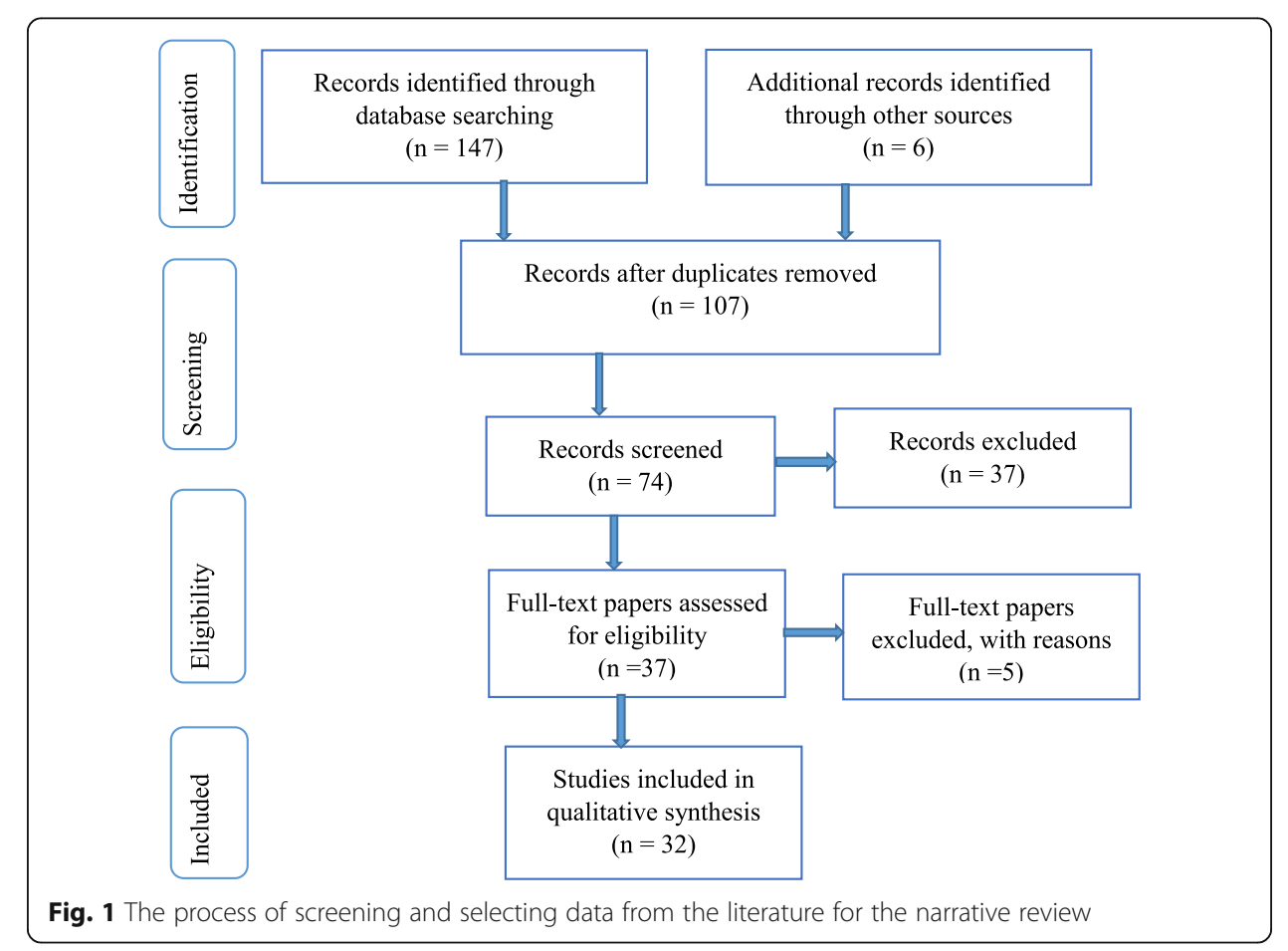


after having first been reported by the WHO in China, and 1 month after it arrived in northern Italy-subsequently and for a period considered the epicenter of the diseaseit was to be expected that the number of cases would be lower in Africa. As illustrated in Table 1, as of 8 August 2020, a total of 9.2 million COVID-19 tests had been performed in Africa, with over 1 million cases being confirmed carriers of the virus, over 707,877 people have recovered, and 22,966 deaths being registered.

Southern Africa conducted the highest number of tests at 4 million (43\% of the total COVID-19 tests conducted), whereas Central Africa did the least 327,007 (4\%). Southern Africa also has the highest number of cases over 565,003 (56\%), followed by North and West Africa with 171,251 (17\%) and 136,952 (13.6\%) cases, respectively. The highest death toll was recorded in Southern Africa at 11,424 (48\%), followed by North Africa with 7030 (29.3\%) deaths. The countries with the highest number of confirmed cases then were South Africa $(553,188)$, Egypt $(95,314)$, Nigeria $(46,140)$, Ghana (40, 533), and Algeria $(34,693)$. The six countries with the highest virus-related registered deaths are South Africa (10,210), Egypt (4992), Algeria (1293), Nigeria (942), Sudan (773), and Morocco (480).

\section{The dynamic resilience of African states and societies in the face of the COVID-19 pandemic}

Current data show that COVID-19 had a greater impact on countries with more "developed" economies than poorer countries on the continent. On the other hand, urban areas had a higher disease burden than rural parts. We reviewed data from The Coronavirus Resource Centre at Johns Hopkins University, displayed in Table 2, which shows that African countries have case fatality rates ranging from $0.5 \%$ in Ghana to 8.1\% in Chad, compared to $15.0 \%$ for the UK, $14.1 \%$ for Italy, and 3.3\% in Brazil. These relatively low COVID-19 case fatality rates in Africa could be attributed to inefficient social and healthcare data collection systems, although they are more likely due to the youthfulness of African populations [41].

\section{The impact of COVID-19 on the informal economy of Africa and the GDP crisis}

As much as $80-90 \%$ of economic activities in sub-Saharan Africa derive from the informal sector, which in turn contributes up to $40 \%$ to the GDP [42, 43]. The outbreak of the COVID-19 pandemic has profoundly affected this economic sector, which involves informal workers and enterprises [42], in such activities as providing accommodation and food services, manufacturing, wholesale, and the retail trade, including over 500

Table 1 COVID-19 tests, confirmed cases, deaths, and active cases in African regions

\begin{tabular}{lllll}
\hline Region & Tests $\boldsymbol{N}(\%)$ & Confirmed cases $\boldsymbol{N}(\%)$ & Recovered $\boldsymbol{N}(\%)$ & Deaths $\boldsymbol{N}(\%)$ \\
\hline North Africa & $1,736,200(20)$ & $171,251(17)$ & $99,881(14.5)$ & $6989(29.3)$ \\
Central Africa & $327,007(4)$ & $50,067(5)$ & $36,454(5)$ & $952(4.3)$ \\
West Africa & $1,193,973(14)$ & $136,952(13.5)$ & $106,986(15.5)$ & $2042(9)$ \\
East Africa & $1,685,411(19.5)$ & $85,801(8.5)$ & $47,612(7)$ & $1909(8.5)$ \\
Southern Africa & $3,681,823(42.7)$ & $565,003(56)$ & $400,065(58)$ & $11,024(48)$ \\
Total & $8,624,414(100)$ & $1,009,074(100)$ & $690,998(100)$ & $22,916(100)$ \\
\hline
\end{tabular}

Source: World meter and Johns Hopkins University as of 8 August 2020 [12, 13] 
Table 2 COVID-19 case fatality rates, comparisons among several countries

\begin{tabular}{llll}
\hline Country & Number of cases & Deaths & Case fatality rate \% \\
\hline Sudan & 11,894 & 773 & 6.5 \\
Nigeria & 46,140 & 942 & 2.0 \\
Chad & 942 & 76 & 8.1 \\
Ghana & 40,533 & 206 & 0.5 \\
Algeria & 34,693 & 1293 & 3.7 \\
South Africa & 553,188 & 10,210 & 1.8 \\
Egypt & 95,314 & 4,992 & 5.2 \\
Kenya & 25,837 & 418 & 1.6 \\
Ethiopia & 22,253 & 390 & 1.8 \\
India & $2,212,429$ & 44,457 & 2.3 \\
USA & $5,166,319$ & 165,269 & 3.2 \\
Brazil & $3,018,286$ & 100,667 & 3.3 \\
Italy & 250,566 & 35,205 & 14.1 \\
UK & 310,825 & 46,574 & 15.0 \\
France & 197,921 & 30,324 & 12.9 \\
\hline
\end{tabular}

Source: The Coronavirus Resource Center at Johns Hopkins University 9 August 2020 [41]

million farmers who were producing for the urban market. Logistical challenges within supply chains, particularly cross-border and domestic restrictions of movement, may lead to disruptions in the food supply, undermining informal workers' food security. Also, informal produce markets play an essential role in ensuring food security in many countries, both as a source of food and a place for smallholder farmers to sell their goods. Their closure would lead to increased food insecurity and poverty [44].

The overwhelming majority of workers in the informal economy experience a heightened exposure to occupational health and safety risks due to a lack of appropriate protection and an increased likelihood that they will suffer from illness, accidents, or death. COVID-19 adds to these risks. If they fall sick, most workers, including migrants, do not have guaranteed access to medical care and no income security through sickness or employment injury benefits [45]. If they are unable to access health care, the virus would spread more widely, with fatal consequences. If they can access health care, many will incur out-of-pocket costs that will force them to go into debt or to sell their productive assets, plunging them into deeper poverty $[45,46]$.

Table 3 presents a comparison of projected changes in the gross domestic products (GDP) of various African states before, currently, and after the pandemic has passed. Table 3 illustrates that the GDP for Africa as a whole is anticipated to shrink from growing at $2.4 \%$ before the outbreak to declining by 2.4 to $5.1 \%$ during its height; some projections show that it will rise to $4.1 \%$ thereafter. The GDP of sub-Saharan Africa and the middle- and low-income countries is reported to change by $-1.6 \%,-3 \%$, and $1.6 \%$ respectively during the COVID-19, with a projected growth of $4.2 \%, 4.9 \%$, and $4.9 \%$ respectively after the pandemic has passed [35, 47].

The health, social, economic, and political impacts of the COVID-19 pandemic in Africa are outlined in Table 4. The consequences for health are overwhelming, adding to the continent's already under-resourced health systems and premature deaths due to such underlying conditions as lower respiratory tract infection, HIV/AIDS, diarrheal 
Table 3 Projected estimates of GDP for various African regions and individual countries before, currently, and post-COVID-19 outbreak $[35,47]$

\begin{tabular}{|c|c|c|c|}
\hline Gross domestic product & Pre (2019) (\%) & During (2020) (\%) & Post (2021) (\%) \\
\hline Africa & 2.4 & -2.4 to -5.1 & 4.1 \\
\hline SSA & 3.1 & -1.6 & 4.2 \\
\hline $\mathrm{OE}$ & 1.7 & -2.9 & 2.5 \\
\hline Angola & -1.5 & -1.4 & 2.6 \\
\hline Chad & 3 & -0.2 & 6.1 \\
\hline Gabon & 3.4 & -1.2 & 3.6 \\
\hline Nigeria & 2.2 & -3.4 & 2.6 \\
\hline DRC & -0.9 & -2.3 & 3.4 \\
\hline MIAC & 2.3 & -3 & 4.9 \\
\hline Cameroon & 3.7 & -1.2 & 4.1 \\
\hline Ivory Coast & 6.9 & 2.7 & 8.7 \\
\hline Ghana & 6.1 & 1.5 & 5.9 \\
\hline Senegal & 5.3 & 3 & 5.5 \\
\hline South Africa & 0.2 & -5.8 & 4 \\
\hline Zambia & 1.5 & -3.5 & 2.3 \\
\hline LIAC & 5.6 & 1.6 & 4.9 \\
\hline DRC & 4.4 & -2.2 & 3.5 \\
\hline Ethiopia & 9.0 & 3.2 & 4.3 \\
\hline Kenya & 5.6 & 1 & 6.1 \\
\hline Madagascar & 4.8 & 0.4 & 5.0 \\
\hline Mali & 5.1 & 1.5 & 4.1 \\
\hline Tanzania & 6.3 & 2 & 4.6 \\
\hline Rwanda & 10.1 & 3.5 & 6.7 \\
\hline Uganda & 4.9 & 3.5 & 4.3 \\
\hline
\end{tabular}

SSA Sub-Saharan Africa, OE Oil exporters, MIAC Middle-income countries, LIAC Low-income countries

diseases, malaria, and tuberculosis, which collectively accounted for over 3 million premature deaths in 2016 [47, 48]. In many rich countries, comorbidities complicate the health outcomes of people with COVID-19; in the case of large populations that are undernourished and experience underlying medical conditions, these may put them at increased risk of succumbing to the virus, but this effect is unknown. The poor health service infrastructure on the continent also makes it unlikely that many of those who are infected will be able to receive the care needed at appropriately equipped facilities [24].

The outbreak of the pandemic has greatly affected the social lives of Africans, limiting material sharing, disrupting family lives, and breaking down social cohesion due to social distancing and enforced isolation. Most educational institutions in Africa have been closed. Traditional life in Africa is cohesive and based on mutual dependence that makes social distancing and isolation very difficult. The lockdowns imposed by national governments not only exacerbate existing inequalities but have contributed to the victimization of women with an increase in rape cases [49], of disabled people and the elderly who are the most economically deprived, vulnerable segment of the population [50]. Moreover, produce markets have been closed, limiting people's access to food sources that have resulted in starvation among vulnerable communities, which were already living below the poverty line (Table 4). In some African countries such as 
Table 4 Health, social, economic, and political impacts of COVID-19 in Africa [13, 41, 52-66, 69-85]

\begin{tabular}{|c|c|}
\hline Type & Impact \\
\hline Health impact & $\begin{array}{l}1,039,678+\text { confirmed cases and } 22,966+\text { deaths } \\
\text { Increased risk of morbidity and mortality among people with comorbidities, disabilities, and } \\
\text { the elderly } \\
\text { Victimization of frontline healthcare workers and increased strain on under-resourced health } \\
\text { systems } \\
\text { Lack of appropriate medical treatment infrastructure } \\
\text { Increased burden on existing diseases like HIV/AIDS, tuberculosis, malaria, diarrhea, and } \\
\text { lower respiratory tract infections }\end{array}$ \\
\hline Social impact & $\begin{array}{l}\text { Breakdown in social cohesion following social distancing and interpersonal isolations } \\
\text { Majority of academic institution closed } \\
\text { Travel bans at international, national, and local levels } \\
\text { Food markets closed, limited access to food sources } \\
\text { Starvation increased among vulnerable communities } \\
\text { Religious gatherings restricted } \\
\text { Fear-borne isolation and discrimination created } \\
\text { Huma rights violation, growth in illegal practices such as increased crime } \\
\text { False news on social media leads communities to incorrect virus prevention responses } \\
\text { Exacerbated inequalities, victimization of women and the elderly }\end{array}$ \\
\hline Economic impact & $\begin{array}{l}\text { Suspension of the aviation and shipping industries for goods and people } \\
\text { Primary, secondary, and tertiary industries affected by varying states of lockdown } \\
\text { Production of domestic products limited } \\
\text { Tourism industry paused and possibly affected long-term } \\
\text { Value of supply chains decreased } \\
\text { Import and exports diminished, affecting foreign revenue } \\
\text { Trade and industry suspended } \\
\text { Increased debt to address the pandemic } \\
\text { Supply and demand for certain products reduced } \\
\text { Financial recession/depression } \\
\text { Increase in unemployment with reduced per-capita income } \\
\text { Increased pressure on monetary and fiscal policies }\end{array}$ \\
\hline Political impact & $\begin{array}{l}\text { Governmental, non-governmental, and private sector organizations closed } \\
\text { Countries shut their borders, preventing the movement of goods and services } \\
\text { Discrimination of refugees and immigrants increased } \\
\text { Evacuation of citizens to their home countries result in distrust among leaders } \\
\text { Postponement of national elections exacerbate conflicts and unrest } \\
\text { Implementation of measures like handwashing may not be appropriate for Africa }\end{array}$ \\
\hline
\end{tabular}

Ethiopia, Kenya, South Africa, and Uganda, lockdowns have resulted in the violation of human rights, the killing of citizens by security forces, and increased traditional crime [28]. This, in turn, has resulted in outbreaks of social unrest, and further impoverishment of communities [51].

Many countries in Africa were already economically compromised by corruption, maladministration, and poor political leadership [39, 47]. Nevertheless, some have shown notable economic growth over the last half-decade, such as Djibouti, Ethiopia, Guinea, Ivory Coast, Senegal, and Tanzania [39, 52]. Many countries have high formal unemployment rates, with people relying on small-scale farming and informal trading to make a living. In those countries that have implemented measures such as lockdowns, which have brought economies to a standstill, many thousands of jobs have been lost, resulting in a growing population who have no reliable source of income [40, 52]. At a national level, some features of the economic impact of COVID-19 prevention measures are the suspension of informal economic sectors such as street vendors and small informal shops in townships called spaza shops [43]. Additional consequences are a reduction in per capita income and the trade-in domestic products, a decline in the value of supply chains, and increased pressure on fiscal policies and debt, all of which can lead to financial recessions or depression [39, 40, 52]. 
The prominent political impacts of COVID-19 depicted in Table 4 show an increase in discrimination against refugees and immigrants; the closing of national borders, preventing the movement of goods and services; a breakdown in formerly close relations among African nations; and the evacuation of citizens to their home countries resulting in distrust among leaders [53]. Also, the implementation of measures like handwashing may not be appropriate for Africa due to a shortage of running water [53]. Moreover, postponement of national elections has resulted in deadly conflict, distrust, and conflict between political opposition parties and the ruling governments in some African countries such as Ethiopia [54].

\section{Discussion}

In this narrative review, we aimed to establish the number of COVID-19 cases, recoveries, and deaths, their impact on the informal economic sector as well as projections of gross domestic product (GDP) changes in Africa pre-, during, and post-epidemic. It also aimed to determine the health, social, economic, and political crisis of the COVID-19 outbreak in Africa as well as the implications of the lockdowns imposed to stop its spread in African populations.

\section{Pre-COVID-19 Africa context}

The pre-COVID-19 healthcare situation on the continent focused mainly on infectious communicable diseases such as HIV/AIDS, malaria, tuberculosis, cholera, and other health-related issues like maternal and under five-child mortality, and the usual low emphasis on non-communicable diseases (NCDs) [55]. The pre-COVID-19 social factors in Africa are diverse and unifying. For instance, there is a continuous movement of African communities from one region of the continent to the other region legally for visiting, tours, trade, education, meetings, and/or training or through illegal migration by the initiative of human illicit traffic workers. There is also regular mass worshipping in churches, mosques, beaches, and socialization around campfires with some portions of the population visiting nightclubs, music and cinema concerts, mass marketing, social works, wedding, and funeral ceremonies [19]. However, all the above activities changed due to the COVID-19 pandemic as the government of each African country implemented strategies to protect the life, health, economy, and rights of their respective citizens.

Economies pre-COVID-19, specifically regarding informal sectors and formal economies in the African context, are unique. The informal sector, for example, comprises economic activities that circumvent costs and is excluded from the benefits and rights incorporated in laws and administrative rules covering property relationships, commercial licensing, labor contracts, torts, financial credit, and social systems vis-à-vis to the formal economy. Whereas labor laws protect formal economies, COVID-19 exposed the informal sector (the precarious nature of informal work), as evidenced by the absence of contracts or income protection [45].

Last but not the least issue is the pre-COVID-19 political situation of Africa, where 22 countries prepared for national elections [56]. Elections provide avenues for citizens to hold their leaders accountable through either endorsing their legitimacy or replacing them if they have performed abysmally with elections in Africa characterized by fear 
and panic as it is considered a 'do-or-die' affair [57]. With the ongoing COVID-19 pandemic, there are uncertainties as to whether countries will proceed with elections under their respective election calendars. More specifically, there are concerns about how some autocratic leaders may take advantage of this pandemic to prolong their stay by postponing elections to a later date or even indefinitely [57].

\section{Morbidity, mortality, and recoveries}

Although the pandemic arose in China, the COVID-19 outbreak in Africa with its massive morbidity and mortality in African populations added to the existing threat of infectious and chronic diseases they are already predisposed to [58]. At the time of writing this narrative review, the cases and mortality associated with the virus are higher in the North African region, followed by the Western and Southern African regions [59]. A modeling study in Africa supports the finding of our study depicting that by June 30, 2020, nearly 16.3 million people in Africa will contract COVID-19 with the North African region the most affected area by the virus while the East African region will be the least affected. Collective cases on June 30 are projected to range about 2.9 million in Southern Africa, 2.8 million in Western Africa, and 1.2 million in Central Africa [60, 61]. This variation in caseload and mortality might be due to lower levels of socioeconomic development and are likely to record less and slower transmissions at the early stages of the pandemic than higher levels of socio-economic development [62-65].

\section{Health crisis}

The results of our narrative review depict a greater health crisis of the COVID-19 outbreak in Africa. This could be ascribed to the already existing under-resourced health care systems and premature deaths, HIV/AIDS, lower respiratory tract infections, diarrheal diseases, malaria, and tuberculosis already accounting for over 3 million deaths in Africa in 2016 [66-68]. While in many developed countries the comorbidities complicate the health outcomes of people with COVID-19, the effect on larger populations who are undernourished and have conditions that may well put them at increased risk of succumbing to the virus is unknown [69]. The limited health service infrastructure also makes it unlikely that many of those who are infected will be able to seek health care at appropriately equipped facilities [25, 70].

\section{Social crisis}

The social crisis posed on African populations is devastating, including false news [71], racism, and discrimination $[71,72]$ as one of the restraints that block the initial control and management of the COVID-19 pandemic outbreak. This could be ascribed to life in Africa that is cohesive and based on dependence, which makes social distancing and isolation very difficult. The findings of our study indicated that the impact of COVID19 is very high among vulnerable people, such as women, older people, people with disabilities, and a higher mortality rate among comorbid individuals [5, 73]. Commentary on Israel's minority group by [74] substantiated the finding of our review stating that older people and people with disabilities and comorbidities are marginalized in all circumstances during the outbreak of COVID-19 in Africa. It could also be due to a lower level of resistance in comorbid and older people than young and non-comorbid 
individuals with the literature affirming the finding of our review indicating that hypertension, diabetes, cardiovascular disease, kidney disease, and respiratory disease the most prevalent comorbidities [75].

The results of this review showed the closure of food markets, limited access to food sources, which in turn resulted in starvation with many households not being able to access or afford food. Evidence shows that the outbreak of COVID-19 can cause a considerable rise in poverty among vulnerable households, including decreased access to food [26]. This could also be attributed to a loss of income during the lockdown. Investigators corroborate the findings of our review, revealing a disparate understanding and awareness of the African community about the COVID-19 pandemic with the western African countries showing a better level of knowledge about the virus, these could be due to lessons learned from the Ebola outbreak [76].

\section{Economic crisis}

Many countries in Africa have high formal unemployment rates, a reduced per-capita income, and no reliable source of income with people relying on small-scale farming and informal trading to make a living. In this regard, researchers indicate that many countries in Africa are already economically compromised due to corruption, maladministration, and poor political leadership. At the same time, some have shown considerable economic growth over the last half decades, such as Ethiopia, Ivory Coast, Djibouti, Senegal, Guinea, and Tanzania [52, 77].

Despite a few countries showing economic growth, the outbreak of the COVID-19 pandemic poses a looming impact on the already under strained African economy. Researchers corroborated our results, indicating that some features of the economic impact of COVID-19 prevention measures are a decline in the GDP and the value of supply chain and increased pressure on fiscal policies and debt $[52,78]$. The results of our review depict a decline in economic growth in Africa of $2.4 \%$ pre-COVID-19 in 2019 [39] to between -2.4 and $-5.1 \%$ during the outbreak of the COVID-19 pandemic era $(2020)[41,52]$. The lockdown decreased production and increased cost to curve, the pandemic could contribute to this prediction. Supporting the results of our finding, a situational study by the United Nations Economic Commission for Africa predicts economic growth of less than $-3.3 \%$ for the African region in 2020 [79]. This could be due to the reduction of wide-ranging export African regions share with the rest of the world than within African regions. Substantiating our finding, a study in Kenya predicts a decline in the five sector's contributing to the GDP such as agriculture, tourism, construction, infrastructure development, and manufacturing post-COVID-19 [80]. Moreover, the findings of our review reflected the expectation of a variation of decline in GDP change across African regions before and during the COVID-19 pandemic with a greater GDP loss (-3\%) observed in the middle-income countries, followed by the whole of Sub-Saharan Africa (- 1.6\%) during the outbreak of the COVID-19 pandemic $[39,40,52]$. The disparity could be the result of the different states of lockdown and the differences these African regions have in the levels of socio-economic and trade partnership with Europe, China, and America [60, 61]. A study by the World Banking Group depicted that the majority of countries in the African region will show a decline in GDP, which was $2.4 \%$ pre-COVID-19, and reduced to $-2.4 \%$ during the outbreak of 
the COVID-19 pandemic period [52, 81]. The decline of GDP is likely to be the result of decreased import and export, job losses due to the lockdown, reduced production of export commodities, and increased debt to address the pandemic [82].

\section{Political crisis}

The political impact of COVID-19 is overwhelming as a result of the existing fragile and weak government structure in addition to the stated health, social, and economic impacts [77]. The findings of our narrative review revealed a breakdown in the connection among African nations and the closing of national borders, evacuation of citizens to their home countries that result in mistrust between frontrunners, and execution of actions that may not be suitable for Africa [51, 83]. In this regard, during the initial outbreak of the COVID-19 pandemic, political decisions taken by African leaders were encouraging, possibly due to fear of their under-strained health system, limited quality health facilities, and an under-strained economy [84]. Also, despite African countries' public health emergency system that is constrained, the action taken by African leaders to curve the spread of the COVID-19 outbreak is not only faster but also highly acknowledged; they declared a public health emergency and banned irrelevant public movement, followed by lockdown to minimize the possibility of the disease outbreak in their respective countries [53, 84]. Aligned with the differences in economies, health systems, and lifestyles among western and African populations, the health outcome, social impact, and economic toll in both developed and developing countries remain disparate [85]. This might be the result of the lack of social support, far more people living on or below the poverty line, and the fact that more people are self-employed or not employed in the formal sector in African regions.

\section{Implications}

Most African countries' health care facilities and resources are under stress. If the spread of the pandemic endures for as long as it is predicted, the secondary effects of the COVID-19 pandemic will swiftly become an economic emergency, leading the world towards a recession, severely impacting African countries with limited resources and the most impoverished populations. Moreover, many African countries have implemented WHO-developed COVID-19 management strategies and approaches to deal with the pandemic, such as "quarantine, social distancing, self-isolation, usage of water, sanitation, and wash hands practices." However, while these approaches to curb and manage the COVID-19 pandemic outbreak are deemed appropriate and successful in Asian countries such as China and South Korea, the strategies remain challenging, impossible, and unacceptable in African countries due to inequalities, substantial job losses, disparity, and informal economic practices in many African countries. Besides, the lockdown is an obstacle to peace, security, and safety to African countries that are plagued by unrest exhibiting illegal practices such as crime, corruption, and maladministration prolonging the existing poverty, starvation, and inequality.

\section{Conclusion}

The COVID-19 pandemic has impacted and will continue to have a long-term impact on the organization of our health systems, of our production, processing and exchange 
of goods and services, as well as our consumption practices, cultures, and our relationship with life and death. The study we have just evaluated contributes to understanding these changes and their impact. It is the choice of policymakers and other stakeholders to consider these findings in the prevention and response to new epidemics. To successfully address the health, social, economic, and political impact of the COVID-19 pandemic outbreak, a united, active, and well-organized public health emergency reaction is required among leaders, governmental and non-governmental organizations. The success of public health emergency readiness and response is substantially based on the superiority and volume of information accessible during the outbreak of the pandemic. Rapid communiqué and distribution of wrathful information are required to prevent and manage the health, social, economic, and political impact of the COVID19 pandemic and to ensure it is a race neither against death nor against starvation for African populations. Therefore, African countries require culturally relevant and indigenous pandemic managing strategies in years to come to make them responsive to pandemics that could affect their economies, and citizens' health and lives.

\title{
Abbreviations
}

BREC: Biomedical Ethical Review Committee; CFE: Contingency Fund for Emergencies; COVID-19: Coronavirus 19; GDP: Growth domestic product; LIAC: Low-income African countries; MIAC: Middle-income African countries; OE: Oil exporters; RLCDC: Regional and Local Centers of Disease Control and Prevention; SSA: Sub-Saharan Africa; UK: United Kingdom; UKZN: University of KwaZulu-Natal; USA: United States of America; WHO: World Health Organization

\section{Acknowledgements}

No acknowledgements.

\begin{abstract}
Authors' contributions
This manuscript was prepared based on original and unpublished research work. The authors are MD and JG. Both authors have directly participated in the design of the study, collected papers for review, screened papers, collected and summarized data and performed the analysis and interpretation of data, or writing of the manuscript. Both authors of this paper have read and approved the final version of the submitted manuscript. None of the authors had any financial conflicts of interest. The contents of this manuscript have not been copyrighted or published previously and are not now under consideration for publication elsewhere. The contents of this manuscript will not be copyrighted, submitted, or published elsewhere while acceptance by the Public Health Review is under consideration. MD will be responsible for correspondence and will perform the contact between the editors and publishers.
\end{abstract}

Authors' information

The first author is currently a postdoctoral fellow at the University of KwaZulu-Natal, College of Health Science, and in quarantine for 14 days while designing and writing this manuscript. Additionally to the reviewed literature, the points raised in this manuscript are the practical experiences of the corresponding author. The second author is the academic supervisor of the first author at the University of KwaZulu-Natal, College of Health Science, and experienced in publishing different scientific, peer-reviewed articles and book chapters. Both authors have expertise in health information systems, non-communicable diseases, metabolic syndrome, health policies, physical activity, and lifestyle research.

Funding

Not applicable.

Availability of data and materials

All information incorporated in this narrative review can be accessed from both the corresponding author and the second author on a timely appeal.

Ethics approval and consent to participate

Not applicable.

Consent for publication

Not applicable.

Competing interests

The authors declare that they have no competing interests. 
Received: 4 June 2020 Accepted: 27 October 2020

\section{Published online: 16 December 2020}

\section{References}

1. WHO. Coronavirus disease 2019 (COVID-19) Situation Report - 80. Situation Report. 2020

2. Peeri N, Bibi S, Baghbanzadeh M, Change C. The SARS, MERS and novel coronavirus(COVID-19) epidemics, the newest and biggest global health threats: what lessons have we learned? Int Epidemiol Assoc. 2020;12:1-10.

3. WHO. Protocol for assessment of potential risk factors for coronavirus disease 2019 (COVID-19) among health workers in a health care setting. World Health Organ. 2020;2.2:1-44.

4. Chen X, Yu B. First two months of the 2019 coronavirus disease (COVID-19) epidemic in China: real- time surveillance and evaluation with a second derivative model. Glob Health Res Policy. 2020;5(7):1-9.

5. Sharma V, Scott J, Kelly J, Vanrooyen MJ. Prioritizing vulnerable populations and women on the frontlines: COVID-19 in humanitarian contexts. Int J Equity Health. 2020;19(4):4-6.

6. Qian X, Ren R, Wang Y, Guo Y, Fang J, Wu Z, et al. Fighting against the common enemy of COVID-19: a practice of building a community with a shared future for mankind. Infect Dis Poverty. 2020;9(34):4-9.

7. WHO. COVID 19 Public Health Emergency of International Concern (PHEIC). World Health Organ. 2020;1:1-7.

8. ACMM. Spot report: WHO declares the new coronavirus outbreak as a Public Health Emergency of International Concern. Asean Cent Mil Med. 2020;004(4):2-4.

9. WHO. Novel coronavirus (2019 - nCoV). Donor Alert. 2020. Available from: https://reliefweb.int/sites/reliefweb.int/files/ resources/donor-alert.pdf.

10. Ihekweazu C, Agogo E. Africa's response to COVID-19. BMC Med. 2020;18(151):18-20.

11. Tarimo CS, Wu J. The first confirmed case of COVID-19 in Tanzania: recommendations based on lesson learned from China. Trop Med Health. 2020;48(25):1-3.

12. JHU"s. COVID-19 coronavirus tracker: confirmed cases and deaths by country-updated as of 8 August 2020 [Internet]. Johns Hopkins University's coronavirus Covid-19 global cases tracker. Available from: https://easo.org/johns-hopkinsuniversitys-coronavirus-covid-19-global-cases-tracker/.

13. WorldoMeter. Worldometers: Covid-19 case and death tracker; 2020. p. 1-5. Available from: https://www.worldometers info/coronavirus/.

14. Boulos MNK, Geraghty EM. Geographical tracking and mapping of coronavirus disease COVID-19/severe acute respiratory syndrome coronavirus 2 (SARS - CoV - 2) epidemic and associated events around the world: how 21st century GIS technologies are supporting the global fight against outbreaks and epidemics. Int J Health Geogr. 2020; 19(8):1-12 https://doi.org/10.1186/s12942-020-00202-8.

15. Manderson L, Levine S. COVID-19, risk, fear, and fall-out. Med Anthropol. 2020;00(00):1-4 https://doi.org/10.1080/ 01459740.2020 .1746301 .

16. WHO. COVID-19 situation update for the WHO African Region. External Situation Report-20. 2020

17. WHO. COVID-19: situation update for the WHO African Region. External Situation Report-21. 2020

18. lii DEL, Adebisi YA, Lin X. Current efforts and challenges facing responses to 2019-nCoV in Africa. Glob Health Res Policy. 2020;5(21):20-2.

19. Renzaho AMN. The need for the right socio-economic and cultural fit in the COVID-19 response in Sub-Saharan Africa: examining demographic, economic political, health, and socio-cultural differentials in COVID-19 morbidity and mortality. Int J Environ Res Public Health. 2020;17(3445):1-14.

20. Alsan M, Stantcheva S, Yang D, Cutler D. Disparities in COVID-19 reported incidence, knowledge, and behavior. medRxiv Prepr. 2020;2118:1-17.

21. Azour J. COVID-19 pandemic and the Middle East and Central Asia: region facing dual shock: linternational Monetary Fund; 2020.

22. Baldwin-ragaven L. Social dimensions of COVID-19 in South Africa: a neglected element of the treatment plan. Wits J Clin Med. 2020;2(SSI):33-8.

23. Howard B, Han K. African governments failing in provision of water and sanitation, majority of citizens say. Afrobarometer. 2020;349:1-24.

24. Howard B. Even before COVID-19, more than half of Africans experienced lack of needed health care. Afrobarom Dispatch. 2020;352:1-25.

25. Berhan Y, Berhan Y. Will Africa be devastated by Covid-19 as many predicted? Perspective and Prospective. Ethiop J Health Sci. 2020;30(3):1-8.

26. Aluga MA. Coronavirus disease 2019 (COVID-19) in Kenya: Preparedness, response and transmissibility. J Microbiol Immunol Infect. 2020:2019-21 https://doi.org/10.1016/j.jmii.2020.04.011.

27. Gyimah-Boadi E, Logan C. Global response to COVID-19 in Africa must protect lives, livelihoods, and freedoms. Organisation for Economic Co-operation and Development. 2020. Available from: https://oecd-development-matters. org/2020/04/08/global-response-to-covid-19-in-africa-must-protect-lives-livelihoods-and-freedoms/ May 25, 2020 at 6 $11 \% 0 \mathrm{~A}$.

28. Gilbert M, Pullano G, Pinotti F, Valdano E, Poletto C, Boëlle P, et al. Preparedness and vulnerability of African countries against importations of COVID-19: a modelling study. Lancet. 2020;6736(20):1-7.

29. OECD. More than one-third of West Africans have no handwashing facility at home: Organisation for Economic Cooperation and Development; 2020. Available from: http://www.west-africa-brief.org/content/en/more-one-third-westafricans-have-no-handwashing-facility-home

30. Mutongoreya G. COVID 19 Pandemic -Lockdowns and their negative impact on SMMEs in Africa. Gordon Inst Sci. 2020 15:1-5 Available from: https://www.bakermckenzie.com/en/insight/publications/2020/03/the-impact-of-covid19-on-keyafrican-sectors

31. Liu W, Yue X. Response to the COVID-19 epidemic: the Chinese experience and implications for other countries. Int $J$ Environ Res Public Health. 2020;17(2304):1-6

32. ILO. Social protection responses to the COVID-19 crisis: country responses and policy considerations: International Labour Organization; 2020. 
33. Bodewig C, Gentilini UGO, Usman Z, Williams P. COVID-19 in Africa: how can social safety nets help mitigate the social and economic impacts? Africa Development Forum; 2020.

34. Hai A, Chan Y, Rutter V, Ashiru-oredope D, Tuck C, Babar Z. Together we unite: the role of the Commonwealth in achieving universal health coverage through pharmaceutical care amidst the COVID-19 pandemic. J Pharm Policy Pract. 2020;13(13):1-7.

35. OECD. Public integrity for an effective COVID-19 response and recovery: Organisation for Economic Co-operation and Development; 2020.

36. Vilar-compte M, Pérez V, Teruel G, Alonso A, Pérez-escamilla R. Costing of actions to safeguard vulnerable Mexican households with young children from the consequences of COVID-19 social distancing measures. Int J Equity Health. 2020;19(70):4-6.

37. Report S, Asia S. Coronavirus disease (COVID-19) situation report - 120 data. World Health Organ. 2020;120:1-16.

38. Report S, Asia S. Coronavirus disease (COVID-19) situation report - 125. World Health Organ. 2020;125:1-17.

39. ADBG. African Economic Outlook: Africa Macroeconomic performance and prospects: Africa Development Banking Group; 2019. p. 1-214. Available from: https:/www.afdb.org/fileadmin/uploads/afdb/Documents/Publications/2019AEO/ AEO_2019-EN.pdf.

40. ADBG. African Economic Outlook: Developing Africa's Workforce for the Future: Africa Development Banking Group; 2020. p. 1-206. Available from: https://www.afdb.org/en/documents/african-economic-outlook-2020.

41. John Hopkins University of Medicine (JHUM). Mortality analyses: Johns Hopkins Coronavirus Resource Center: John Hopkins University of Medicine; 2020. Available from: https://coronavirus.jhu.edu/data/mortality.

42. Medina L, Jonelis A, Cangul M. The informal economy in Sub-Saharan Africa: size and determinants. IMF Work Pap. 2016;WP17/156:1-31.

43. Dube K, Katende CN. An inclusive response to COVID-19 for Africa's informal workers. 2020. Available from: https://blogs. worldbank.org/africacan/inclusive-response-covid-19-africas-informal-workers Accessed 22 July 2020.

44. Battersby J, Watson V. Urban food systems governance and poverty in African cities. Londone: Routledge; 2019

45. Ataguba JE. COVID-19 pandemic, a war to be won: understanding its economic implications for Africa. Appl Health Econ Health Policy. 2020;18(3):325-8 https://doi.org/10.1007/s40258-020-00580-X.

46. Manderson L, Levine S. COVID-19, risk, fear, and fall-out. Med Anthropol. 2020;39(5):367-70 https://doi.org/10.1080/ 01459740.2020 .1746301$.

47. OECD. COVID-19 and Africa: socio-economic implications and policy responses. Organ Econ Co-operation Dev. 2020;(7): 1-23 Available from: http://www.oecd.org/coronavirus/policy-responses/covid-19-and-africa-socio-economicimplications-and-policy-responses-96e1 b282/.

48. Akuamoah E. Covid-19 and elections in sub-Saharan Africa: what risks for democracy and human rights ? 2020.

49. WHO. COVID-19 situation update for the WHO African region. Extern Situat Rep. 2020;8:1-9.

50. Karamouzian M, Madani N. COVID-19 response in the Middle East and north Africa: challenges and paths forward. Lancet Glob Health. 2020;2019(20):2019-20 https://doi.org/10.1016/S2214-109X(20)30233-3.

51. Frost BI, Osena G, Craig J, Hauck S, Kalanxhi E, Gatalo O, et al. COVID-19 in Middle Africa: national projections of total and severe infections under different lockdown scenarios Overview : COVID-19 in Africa. Cent Dis Dyn Econ Policy. 2020: 1-32 Available from: https://www.medrxiv.org/content/10.1101/2020.09.04.20188102v1.full.pdf.

52. Frost BI, Osena G, Craig J, Hauck S, Kalanxhi E, Gatalo O, et al. COVID-19 in South Africa: national projections of total and severe infections under different lockdown scenarios Overview : COVID-19 in Africa. Cent Dis Dyn Econ Policy. 2020:122 Available from: www.cddep.org.

53. WHO. COVID-19 COVID-19 situation update for the WHO African Region. Extern Situat Rep. 2020;11:1-10.

54. Kanengoni B, Andajani-sutjahjo S, Holroyd E. Improving health equity among the African ethnic minority through health system strengthening: a narrative review of the New Zealand healthcare system. Int J Equity Health. 2020;19(21):1-14.

55. Elovainio R, Pick A. COVID-19 and beyond: how can Africa's health systems cope? Organ Econ Co-operation Dev. 2020; $06: 1-5$.

56. Joffé G. COVID-19 and North Africa. J North African Stud. 2020;0(4):1-8 https://doi.org/10.1080/13629387.2020.1757334.

57. Moulds J. How the threat of COVID-19 is affecting people across Africa: the World Economic Forum COVID Action Platform Africa. World Economic Forumrum. 2020;6:1-6 Available from: https://www.weforum.org/agenda/2020/05/ africa-covid-19-coronavirus-pandemic-food-water-perc/.

58. Microbiol C, Togun T, Kampmann B, Stoker NG, Lipman M. Anticipating the impact of the COVID - 19 pandemic on TB patients and TB control programmes. Ann Clin Microbiol Antimicrob. 2020;19(21):1-6 https://doi.org/10.1186/s12941020-00363-1.

59. Chersich MF, Gray G, Fairlie L, Eichbaum Q, Mayhew S, Allwood B, et al. COVID-19 in Africa: care and protection for frontline healthcare workers. Glob Health. 2020;16(46):1-6.

60. Moosa M. News in the COVID-19 crisis: where do South Africans get their news, and is it trustworthy? IJR. 2020;27:1-7.

61. Devakumar D, Shannon G, Bhopal SS, Abubakar I. Racism and discrimination in COVID-19 responses. Lancet. 2020; 395(10231):1194 https://doi.org/10.1016/S0140-6736(20)30792-3.

62. White K, Lawrence JA, Tchangalova N, Huang SJ, Cummings JL. Socially-assigned race and health: a scoping review with global implications for population health equity. Int J Equity Health. 2020;19(25):1-14.

63. Dunlop A, Lokuge B, Masters D, Sequeira M, Saul P, Dunlop G, et al. Challenges in maintaining treatment services for people who use drugs during the COVID-19 pandemic. Harm Reduct J. 2020;17(26):1-7.

64. Martinez-alvarez M, Jarde A, Usuf E, Brotherton H, Bittaye M, Samateh AL, et al. COVID-19 pandemic in west Africa. Lancet Glob Health. 2020;8(5):e631-2 https://doi.org/10.1016/S2214-109X(20)30123-6.

65. Adegoke Y. African economies will outperform global growth in 2020 despite a lag from its biggest countries. Qurtz Africa. 2020; Available from: https://qz.com/africa/1783714/african-economies-to-watch-in-2020-debt-and-climate-crisis/.

66. UNECA. Economic impact of the COVID-19 on Africa: United Nations Economic Commission for Africa; 2020.

67. You S, Tsowou K, Sommer L, Aidi W, Mevel S, Luke D, Karonga J, Adeyemi A, Desta M, Hasham N, Ruzvidzo T, Rosalie G, Gauci A, Sinha S, Yemeru EA, Zulu J, Lawson D, Mario Y, Ghebru TF, Seck M, Adam J-P, Mofor L, Murombedzi J, Lisinge R, Gatera S, Barka HB, Akinyemi O, Awel Y, Awoyemi B, Bayale N, Chavula H, Ibrahim M, Mpapalika J, Amandine NA, RM. COVID-19 in Africa: protecting lives and economies: United Nations Economic Commission for Africa; 2020. 
68. Odhiambo J, Weke P, Ngare P. Modeling Kenyan economic impact of corona virus in Kenya using discrete-time Markov chains. J Financ Econ. 2020;8(2):1-7.

69. World Banking Group (WBG). Assessing the economic impacts of COVID-19 and policy responses in Sub-Saharan Africa: an analysis of issues shaping Africa's economic future. African's Pulse. 2020;21(April):1-9.

70. Jayaram K, Leke A, Ooko-Ombaka A, Sun YS. Tackling COVID-19 in Africa: an unfolding health and economic crisis that demands bold action: McKinsey and Company; 2020

71. COVID-19 will threaten African political stability. Emerald Insights. 2020:1-5. Available from: https:/www.emerald.com/ insight/content/doi/10.1108/OXAN-DB251710/full/html May 25, 2020 at 7:02\%0A.

72. UN. United Nations Economic Commission for Africa Policy Brief: Impact of COVID-19 in Africa. United Nations. 2020; (20):1-28 Available from: https://www.uneca.org/sites/default/files/PublicationFiles/sg_policy_brief_on_covid-19_ impact_on_africa_may_2020.pdf.

73. van Vuuren PJ. Factsheet: Africa's leading causes of death in 2016. World Health Organ. 2019;28:1-6 Available from: https://africacheck.org/factsheets/factsheet-africas-leading-causes-death/ May 25, 2020 at 7:21\%0AThe.

74. Murray CJL. Global, regional, and national age-sex specific mortality for 264 causes of death, 1980 - 2016: a systematic analysis for the Global Burden of Disease Study 2016. Lancet. 2017:390(1151):1980-2016.

75. Tang K, Gaoshan J, Ahonsi B. Sexual and reproductive health (SRH): a key issue in the emergency response to the coronavirus disease (COVID-19) outbreak. Reprod Health. 2020:17(59):17-9.

76. Carrieri D, Peccatori FA, Boniolo G. COVID-19: a plea to protect the older population. Int J Equity Health. 2020;19(72):5-8.

77. De Waal A. Governance implications of epidemic disease in Africa: updating the agenda for COVID-19. London Sch Econ Polit Sci. 2020:1-10 Available from: http://eprints.Ise.ac.uk/104471/.

78. Ncube M, Lufumpa CL, Vencatachellum D, Murinde V. Aging population challenges in Africa. 2 African Dev Bank. 2011; $1(1): 1-19$.

79. Amimo F, Lambert B, Magit A. What does the COVID-19 pandemic mean for HIV, tuberculosis, and malaria control? Trop Med Health. 2020;48(32):1-4.

80. Judd Devermont EO. COVID-19 is an African political crisis as much as a health and economic emergency: Center for Strategic \& International Studies; 2020. p. 1-6. Available from: https:/www.csis.org/analysis/covid-19-african-politicalcrisis-much-health-and-economic-emergency.

81. ICG. The COVID-19 pandemic and deadly conflict: managing the politics of Ethiopia's COVID-19 crisis: International Crisis Group; 2020. Available from: https://www.crisisgroup.org/africa/horn-africa/ethiopia/managing-politics-ethiopias-covid9-crisis.

82. Gouda HN, Charlson F, Sorsdahl K, Mph SA, Ferrari AJ, Erskine H, et al. Burden of non-communicable diseases in subSaharan Africa, 1990 - 2017: results from the Global Burden of Disease Study. Lancet Glob Health. 2019;7(10):e1375-87 https://doi.org/10.1016/S2214-109X(19)30374-2.

83. EISA. Electoral Institute for Sustainable Democracy in Africa. 2020 African election calendar, 2020 African election calendar; 2020. p. 1-3. Available from: https://www.eisa.org.za/calendar.php Accessed 2 July 2020

84. Chattu VK, Yaya S. Emerging infectious diseases and outbreaks: implications for women's reproductive health and rights in resource- poor settings. Reprod Health. 2020:17(43):1-5.

85. Waitzberg R, Davidovitch N, Leibner G, Penn N, Brammli-greenberg S. Israel's response to the COVID-19 pandemic: tailoring measures for vulnerable cultural minority populations. Int J Equity Health. 2020;19(71):7-11.

\section{Publisher's Note}

Springer Nature remains neutral with regard to jurisdictional claims in published maps and institutional affiliations.

\section{Ready to submit your research? Choose BMC and benefit from:}

- fast, convenient online submission

- thorough peer review by experienced researchers in your field

- rapid publication on acceptance

- support for research data, including large and complex data types

- gold Open Access which fosters wider collaboration and increased citations

- maximum visibility for your research: over $100 \mathrm{M}$ website views per year

At $\mathrm{BMC}$, research is always in progress.

Learn more biomedcentral.com/submissions 